In particular, the writers gratefully acknowledge the interest, support, and encouragement of Julius $\mathrm{H}$. Strassburger.

Vernon Bye, of the Minnesota Mines Experiment Station, is credited with a portion of the analytical work.

\section{References}

${ }^{1}$ G. M. Schwartz: Iron Ore Sinter. AIME Trans., 1929, vol. 84 pp. 39-69.

R. Hay and J. McLeod: Some Aspects of Sintering Iron Ores. Scotland Iron and Steel Institute, 1942-1943, vol. 50 pt. 6, pp. 55-64.

L. Cohen: Radiographic Studies of the Process of Sintering Iron Iron and Steel Institute, London, 1953 , vol. 175, pp. 160-166.
4 R. Wild: The Chemical Constitution of Sinters. Journal Iron and teel Institute, London, 1953, vol. 174, pp. 131-135. torets Annaler, 1945, vol. 129, no. 8, pp. 383-446.

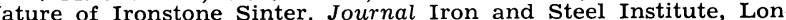
don, 1954, vol. 177 , pp. 316-323.

7 A. R. Powell and J. H. Thompson: Study of the Desulphurization of Coke by Steam. Coal Mining Investigations Bulletin No. 7 , Carnegie Institute of Technology, Pittsburgh, 1923.

$8 \mathrm{~J}$. H. Thompson: Forms of Sulphur in Steamed Coke and Their Action in the Blast Furnace. Report of Investigations No. 2518, U. S.

Bureau of Mines, Washington, D. C., 1923. the Use of Sulphur as Fuel in the Sintering of Iron Ores. Canadian Mining Journal, 1952, vol. 73 , no. 7 , pp. $51-56$

Discussion of this paper sent (2 copies) to AIME by Sept. 1, 1956 will appear in AIME Transactions Vol. 209, 1957, and in JourNA OF METALS, October 1957 .

Technical Note

\title{
Metallographic Identification and Crystal Symmetry of Titanium Hydride
}

\author{
by L. D. Jaffe
}

$I^{\mathrm{N}}$ $\mathrm{N}$ previous metallographic work on titanium and its alloys, difficulty has been encountered in distinguishing spheroidal particles of titanium hydride, dispersed in $\alpha$-titanium, from other phases that may be present, such as $\beta$-titanium. This problem is common in examination of commercial unalloyed titanium. ${ }^{1}$

In the course of an investigation of the $\mathrm{Ti}-\mathrm{H}$ phase diagram, it was noted that titanium hydride, dispersed in a matrix of $\alpha$-titanium, showed strong optical anisotropy when examined under polarized light. With sensitive tint illumination, particles of the hydride, when the stage is rotated, changed from bright yellow to bright blue in color. Since $\beta$ titanium is cubic, it showed no color change on rotation, remaining dark gray or blue-gray. Although $\alpha$-titanium is hexagonal, it showed only a minor color change, going from pale pinkish-blue to pale purplish-blue. These colors could be modified somewhat by adjustment of the illumination. They were observed in specimens mechanically polished, both without etching and after etching with hydrofluoric acid-nitric acid mixtures in either water or glycerine. The strong color change of the hydride seems to offer a simple method for its metallographic identification.

Optical anisotropy of titanium hydride is inconsistent with its accepted face-centered-cubic structure. ${ }^{2}$ Samples of iodide titanium containing 6 to 40 atomic pct deuterium were prepared for diffraction studies. After deuterating and slow cooling ${ }^{1}$ the samples were held $211 / 2 \mathrm{hr}$ at $400^{\circ} \mathrm{C}$, water quenched, held $61 \mathrm{hr}$ at $100^{\circ} \mathrm{C}$ and quenched, then held $641 / 2 \mathrm{hr}$ at $255^{\circ} \mathrm{C}$ and quenched. Debye exposures with $\operatorname{MoK} \alpha$ X-rays and $1.111 \AA$ neutrons were made at room temperature of samples asdeuterated and after the $100^{\circ}$ and $255^{\circ} \mathrm{C}$ treatments. Table I shows the lines observed, in addition to those attributable to $\alpha$-titanium. These data show that the hydride phase was not cubic, but probably tetragonal. The titanium atoms appeared to form a body-centered-tetragonal lattice complex, two titanium atoms per cell, with approximate dimensions:

L. D. JAFFE, Member AIME, formerly with Watertown Arsenal, Watertown, Mass., is now Chief, Materials Section, Jet Propulsion Laboratory, California Institute of Technology, Pasadena, Calif.

TN 333E. Manuscript, Mar. 20, 1956.

\begin{tabular}{|c|c|c|c|c|}
\hline \multirow[b]{2}{*}{$\begin{array}{l}\text { Interplanar } \\
\text { Spacing, } \mathbb{A}\end{array}$} & \multicolumn{2}{|c|}{ Relative Integrated Intensity } & \multicolumn{2}{|c|}{$\begin{array}{l}\text { Lattice Complex } \\
\text { Indexing }\end{array}$} \\
\hline & $\mathbf{X}$-Ray* & Neutron* & BCT $\uparrow$ & FCT $\uparrow$ \\
\hline $\begin{array}{l}2.98 \\
2.50 \\
2.20 \\
2.10 \\
1.81 \\
1.55 \\
1.33 \\
1.27 \\
1.01 \\
0.99\end{array}$ & $\begin{array}{r}0 \\
50 \\
<100 \\
10 \\
0 \\
30 \\
<3) \\
<35 \\
<7 \\
10 \\
0\end{array}$ & $\begin{array}{r}25 \\
<35 \\
<100 \\
50 \\
20 \\
30 \\
<50 \\
<100 \\
\}<25\end{array}$ & $\begin{array}{c}\ddagger \\
(101) \\
(110) \\
(002) \\
\ddagger \\
(200) \\
(211) \\
(103) \\
(301) \\
\left\{\begin{array}{l}(104) \ddagger \\
(310) \\
(213)\end{array}\right.\end{array}$ & $\begin{array}{l}(101) \ddagger \\
(111) \\
(200) \\
(002) \\
(211) \ddagger \\
(220) \\
(311) \\
(113) \\
(331) \\
(114) \ddagger \\
(420) \\
(313)\end{array}$ \\
\hline
\end{tabular}

$*$ indicates lines overlapped by lines of $\alpha$-titanium, so only * ${ }^{*}$ indicates lines overlapped by lines of $\alpha$-titanium

maximum limit to intensity of hydride line could be set. $\dagger \mathrm{BCT}$ and FCT indicate bod

tered-tetragonal, respectively. $\neq$ indicates neutron lines not fing indexing of latice complex deuterium atoms.

$a=3.12 \AA, \quad c=4.18 \AA$, and $c / a=1.34 \AA$. This is equivalent to a face-centered-tetragonal complex, four titanium atoms per cell, with approximate dimensions: $a=4.42 \AA, c=4.18 \AA$, and $c / a=0.946 \AA$. The presence of the 2.98 and $1.81 \AA$ neutron lines indicates that the true Bravais lattice is not identical with this lattice complex, but may be primitive tetragonal with dimensions some multiple of-those of the complex.

The relative intensities of the hydride and $\alpha$ titanium X-ray lines as functions of overall composition indicated that the hydride, presumably in equilibrium with the $\alpha$ at $100^{\circ}$ to $255^{\circ} \mathrm{C}$, contained more than 62 atomic pet $\mathrm{H}$.

\section{Acknowledgments}

The experimental work covered in this report was done at Brookhaven National Laboratory, through the courtesy of D. Gurinsky. The cooperation of J. Sadofsky, O. Kammerer, A. McReynolds, and A. Cendrowski. is gratefully acknowledged.

\section{References}

1 G. A. Lenning, C. M. Craighead, and R. I. Jaffee: Constitution and Mechanical Properties of Titanium-Hydrogen Alloys. AIME and Mechanical Properties of Titanium-Hydrogen Alloys. AIME Trans., Chretien, W. Freundlich, and M. Bichara: Etude du systeme Rendus, 1954, vol. 238, pp. 1423-1424. 